Jurnal Ners Volume 4 Nomor 2 Tahun 2020 Halaman $30-39$
JURNAL NERS
Research \& Learning in Nursing Science
http://journal.universitaspahlawan.ac.id/index.php/ners

\title{
DAMPAK COVID-19 TERHADAP PERLAMBATAN EKONOMI SEKTOR UMKM
}

\author{
Maya Intan Pratiwi, SH., MH \\ Universitas Pahlawan Tuanku Tambusai
}

\begin{abstract}
Abstrak
Dalam perekonomian Indonesia, Usaha Mikro, Kecil, dan Menengah (UMKM) adalah kelompok usaha yang memiliki jumlah paling besar. Selain itu, kelompok ini terbukti tahan terhadap berbagai macam goncangan krisis ekonomi. Maka sudah menjadi keharusan untuk melakukan penguatan kelompok UMKM yang melibatkan banyak kelompok. Kriteria usaha yang termasuk dalam UMKM telah diatur dalam payung hukum berdasarkan undang-undang. Dari hasil penelitian dapat disimpulkan, Pemerintah telah mengeluarkan beberapa kebijakan terkait perlambatan ekonomi akibat wabah Covid-19 yaitu dengan memberikan insentif di sektor pariwisata, menambah hari cuti bersama, dan keringanan pembayaran utang bagi pelaku UMKM. Selain itu, Pemerintah membuka call center untuk menerima laporan dan pengaduan dari koperasi dan UMKM yang terdampak wabah Covid-19. DPR dengan fungsi pengawasannya perlu mendorong pemerintah untuk memanfaatkan keunggulan geografis ini menjadi peluang apabila pemerintah membangun titik-titik UMKM di daerah bebas Covid-19, terutama apabila bertujuan ekspor. Selain itu, pemerintah juga perlu memberikan stimulus untuk menjaga daya beli masyarakat di tengah krisis ini sehingga kemudahan yang diberikan kepada ekonomi dapat terasa manfaatnya. Stimulus tersebut dapat berupa pengurangan tarif listrik dan penurunan harga BBM. Ketersediaan bahan produksi seperti bahan baku juga perlu dijamin supaya kegiatan usaha UMKM tidak terganggu secara signifikan dan mampu kembali ke tingkat produksi normalnya secepat mungkin. Upaya-upaya yang telah dilakukan pemerintah, terlihat masih banyak terpusat pada sektor pariwisata yang memiliki pengaruh besar pada sector UMKM, selain itu kelonggaran kredit juga dianggap sudah tepat untuk meringankan beban UMKM. Namun, bantuan/insentif kepada UMKM khususnya usaha mikro dan kecil masih perlu diperhatikan apalagi mengingat himbauan social distancing saat ini yang berpengaruh besar pada usaha kecil dan mikro yang masih banyak membutuhkan tatap muka.
\end{abstract}

Kata Kunci : Dampak Covid-19, Perlambatan Ekonomi, Sektor UMKM

@ Jurnal Ners Prodi Sarjana Keperawatan \& Profesi Ners FIK UP 2020

$\triangle$ Corresponding author:

Address : Jl. Tuanku Tambusai No. 23 Bangkinang

Email : nersjurnal@gmail.com 


\section{PENDAHULUAN}

Penyebaran virus Covid-19 masih menjadi konsen berbagai negara, terutama yang sudah mengonfimasi kasus positif terinfeksi di negaranya. Berdasarkan situs real time Coronavirus COVID-19 Global Cases, angka terkait kasus ini terus meningkat. Per tanggal 17 Maret, tercatat 188.638 kasus virus Covid-19 merebak di lebih dari 90 negara di dunia. Jumlah kasus tertinggi masih di China, dan diikuti oleh Italia, Iran, Spanyol, dan Korea Selatan. Di Indonesia sendiri jumlah pasien positif terinfeksi Virus Corona (Covid-19) disebut bertambah menjadi 686 orang. Dari jumlah itu, korban meninggal mencapai 55 orang, dengan jumlah yang sembuh 30 orang dan bertambah terus menerus setiap harinya.

Meskipun angka kesembuhan Covid-19 terus meningkat, kemunculan kasus penyebaran Covid-19 juga mengalami peningkatan sehingga ketidakpastian masih terus memengaruhi laju perekonomian global. Moody's Investor Service memprediksi pertumbuhan ekonomi Indonesia pada tahun 2020 akan mengalami perlambatan pada angka 4,8\% terhadap Produk Domestik Bruto (PDB). Nilai ini di bawah pertumbuhan tahun 2019 yang berada di angka 5,02\% Perlambatan ekonomi ini diperkirakan akan berlanjut di tahun 2021 meski dengan disertai sedikit

penguatan yaitu tumbuh $4,9 \%$ saja.

Dalam situasi krisis seperti ini, sektor UMKM sangat perlu perhatian khusus dari pemerintah karena merupakan penyumbang terbesar terhadap PDB dan dapat menjadi andalan dalam penyerapan tenaga kerja, mensubtitusi produksi barang konsumsi atau setengah jadi.

Sesuai dengan Undang-Undang Nomor 20 Tahun 2008 tentang Usaha Mikro, Kecil dan Menengah (UMKM) : ${ }^{1}$

Fahmi Radhi, Kebijakan Ekonomi Pro Rakyat, Republika, Jakarta, 2008, Hlm 3

Jurnal Ners Universitas Pahlawan
1. Usaha Mikro adalah usaha produktif milik orang perorangan dan/atau badan usaha perorangan yang memenuhi kriteria Usaha Mikro sebagaimana diatur dalam UndangUndang ini. Usaha Mikro memiliki kriteria asset maksimal sebesar 50 juta dan omzet sebesar 300 juta.

2. Usaha Kecil adalah usaha ekonomi produktif yang berdiri sendiri, yang dilakukan oleh orang perorangan atau badan usaha yang bukan merupakan anak perusahaan atau bukan cabang perusahaan yangdimiliki, dikuasai, atau menjadi bagian baik langsung maupun tidak langsung dari usaha menengah atau usaha besar yang memenuhi kriteria Usaha Kecil sebagaimana dimaksud dalam UndangUndang ini. Usaha Kecil memiliki kriteria asset sebesar 50 juta sampai dengan 500 juta dan omzet sebesar 300 juta sampai dengan 2,5 miliar.

3. Usaha Menengah adalah usaha ekonomi produktif yang berdiri sendiri, yang dilakukan oleh orang perseorangan atau badan usaha yang bukan merupakan anak perusahaan atau cabang perusahaan yang dimiliki, dikuasai, atau menjadi bagian baik langsung maupun tidak langsung dengan Usaha Kecil atau usaha besar dengan jumlah kekayaan bersih atau hasil penjualan tahunan sebagaimana diatur dalam UndangUndang ini. Usaha Menengah memiliki kriteria asset sebesar 500 juta sampai dengan 10 miliar dan omzet sebesar 2,5 miliar sampai dengan 50 miliar.

Menurut Sri Winarni, Pada umumnya usaha kecil mempunyai ciri antara lain sebagai berikut :

1. Biasanya berbentuk usaha perorangan dan belum berbadan hukum perusahaan.

2. Aspek legalitas usaha lemah.

3. Struktur organisasi bersifat sederhana dengan pembagian kerja yang tidak baku. 
4. Kebanyakan tidak mempunyai laporan keuangan dan tidak melakukan pemisahan antara kekayaan pribadi dengan kekayaan perusahaan.

5. Kualitas manajemen rendah dan jarang yang memiliki rencana usaha.

6. Sumber utama modal usaha adalah modal pribadi.

7. Sumber Daya Manusia (SDM) terbatas.

8. Pemilik memiliki ikatan batin yang kuat dengan perusahaan, sehingga seluruh kewajiban perusahaan juga menjadi kewajiban pemilik.

Berdasarkan uraian di atas, maka penulis tertarik meneliti tentang “Dampak

\section{Covid-19 Terhadap Perlambatan Ekonomi} Sektor UMKM".

Berdasarkan latar belakang masalah di atas, pokok permasalahan dari penelitian ini adalah :

1. Bagaimana Dampak Pelambatan Ekonomi Akibat Covid-19 terhadap UMKM ?

2. Bagaimana Upaya Pemerintah Memperkuat UMKM ?

\section{HASIL PENELITIAN DAN PEMBAHASAN}

\section{Dampak Pelambatan Ekonomi Akibat Covid-19 Terhadap UMKM}

Usaha Mikro Kecil dan Menengah (UMKM) yang mengalami peningkatan yang sangat menggembirakan dikarenakan berhasil menyumbangkan 57\% dari PDB (di dukung oleh data BPS tahun 2006 - 2010) dimana UMKM meningkat bukan hanya dari segi kuantitas melainkan tenaga kerja, modal serta asset mereka. UMKM juga dikatakan usaha ekonomi produktif yang cukup kuat, sekalipun terjadi gejolak atau krisis mereka tidak terkena dampak yang begitu menyedihkan. Hal tersebut dikarena prinsip kemandirian yang dimiliki yang artinya mereka memiliki modal sendiri dan tidak terlalu bergantung pada lembaga lain sehingga membuat mereka kokoh hingga saat ini dan menjadi katup perekonomian negara.

Pencapaian yang sangat menggembirakn bagi UMKM kita tidak didapat hanya dengan sekali mengedipkan mata. Banyak tantangan yang mereka harus lalui dan banyak masalah yang harus mereka selesaikan baik secara modal, tenaga kerja, kegiatan produksi dan hal lainnya. Sehingga apabila terdapat UMKM yang tidak siap dan tak mampu menghindari atau mengatasi gejolak yang datang maka tidak mustahil akan ada juga UMKM yang kolaps. ${ }^{2}$

Berdasarkan masalah-masalah yang dialami oleh koperasi dan UMKM di Indonesia penulis menganalisis dan memiliki strategi penyelesaian masalah-masalah tersebut yang mereka alami agar tak terulang kembali dan terus meningkat baik secara kuantitas maupun kualitas. Strategi yang penulis sarankan, baik bagi pemerintah khususnya Menteri Koperasi dan UMKM, anggota serta pengurus koperasi di seluruh Indonesia dan para owner UMKM di seluruh Indonesia untuk agar memiliki komitmen yang kuat untuk meningkatkan perekonomian Indonesia melalui cara-cara berikut, diantaranya $:^{3}$

1. Penyediaan modal dan akses kepada sumber dan lembaga keuangan. Ditambah dengan pemberian kemudahan (bukan berbelit-belit) dalam mengurus administrasi untuk mendapatkan modal dari lembaga keuangan. Dapat juga melalui pengefektifan dan pengefisienan program Kredit Usaha Rakyat (KUR) yang telah disediakan oleh pemerintah sebelumnya.

2. Meningkatkan kualitas dan kapasitas kompetensi SDM. Melalui pendidikan dan pelatihan baik dilakukan oleh pemerintah maupun oleh koperasi atau UMKM itu

\footnotetext{
2 M. Kuncoro, Perencanaan Daerah : Bagaimana Membangun Ekonomi Lokal, Kota dan Kawasan, Gramedia, Jakarta, 2011, Hlm 4

3 Ibid., Hlm 5
} 
sendiri. Selain itu, untuk meningkatkan kualitas SDM, mereka perlu "dibangunkan" kembali mengapa mereka berada di koperasi, orang yang masih konsisten berusaha mengembalikan mindset orang yang tidak aktif agar mereka mau berorganisasi khususnya koperasi berdasarkan asas dan prinsip-prinsip yang telah ditetapkan.

3. Meningkatkan kemampuan pemasaran UMKM. Pemberian pendidikan mengenai pemasaran atau dengan cara membuka/merekrut tenaga profesional yang ahli dalam hal pemasaran.

4. Meningkatkan akses informasi usaha bagi UMKM.

5. Menjalin kemitraan yang saling menguntungkan antar pelaku usaha (UMKM, Usaha Besar dan BUMN).

6. Melakukan/membuat program goes to goal, yaitu langsung ke tujuan atau sasaran. Dilakukan dengan cara memberikan bantuan baik modal, konsep, dan hal-hal yang dibutuhkan oleh koperasi dan UMKM atau dengan membidik para individu yang memiliki jiwa enterpreneur dengan tetap adanya prinsip prudensial dan adanya manager investasi (meminjam istilah perbankan syariah dimana nasabah yang telah diberi pinjaman tetap terus mendapat pengawasn atau layanan prima dalam pengolahan dana yang). Selama ini banyak orang ahli dalam bidang UMKM mengadakan seminar-seminar demi meningkatnya kualitas dan kuantitas dari UMKM, namun "efek" yang ada dari seminar tersebut tidaklah lama, hanya bertahan sebentar, untuk itu lebih baik mereka mencari langsung terjun ke lapangan untuk mencari orang-orang yang benar-benar serius di UMKM dan jika dilihat potensi usahanya bagus segera dipinjami dana dalam rangka mengembangkan usahanya.
Sejatinya perkembangan UMKM di Indonesia cukup baik, jika ditinjau dari segi jumlah unit usaha maupun jumlah tenaga kerja yang diserap oleh UMKM dalam rangka mengurangi pengangguran. Data BPS (1994) menunjukkan jumlah pengusaha kecil telah mencapai 34,316 juta orang yang meliputi 15,635 juta pengusaha kecil mandiri (tanpa menggunakan tenaga kerja lain), 18,227 juta orang pengusaha kecil yang menggunakan tenaga kerja anggota keluarga sendiri serta 54 ribu orang pengusaha kecil yang memiliki tenaga kerja tetap. ${ }^{4}$

Sejak kemunculannya di akhir tahun 2019, virus Covid-19 telah menyebar di seluruh dunia. Dengan cepatnya penyebaran Covid-19, dampak perlambatan ekonomi global mulai dirasakan di dalam negeri. Mulai dari harga minyak bumi yang jatuh ke arah terendah sejak 1991 pada dua hari lalu, bursa saham yang terjun bebas, serta harga komoditas lain seperti gas dan minyak sawit diperkirakan juga akan tertarik ke bawah apabila permintaan tidak segera pulih.

Industri pariwisata merupakan salah satu industri yang terdampak oleh penyebaran virus ini. Ketua Bali Tourism Board (BTB)/Gabungan Industri Pariwisata Indonesia (GIPI) Bali, Ida Bagus Agung Partha Adnyana mengatakan telah terjadi 40.000 pembatalan hotel dengan kerugian mencapai Rp1 triliun setiap bulan.

Lesunya sektor pariwisata memiliki efek domino terhadap sektor UMKM. Berdasarkan data yang diolah P2E LIPI, dampak penurunan pariwisata terhadap UMKM yang bergerak dalam usaha makanan dan minuman mikro mencapai $27 \%$. Sedangkan dampak terhadap usaha kecil makanan dan minuman sebesar $1,77 \%$, dan usaha menengah di angka $0,07 \%$. Pengaruh virus Covid-19 terhadap unit kerajinan dari kayu dan rotan, usaha mikro akan berada di angka $17,03 \%$. Untuk usaha kecil di sector kerajinan kayu dan rotan $1,77 \%$ dan usaha 
menengah $0,01 \%$. Sementara itu, konsumsi rumah tangga juga akan terkoreksi antara $0,5 \%$ hingga $0,8 \%$.

Padahal, Usaha Mikro, Kecil dan Menengah (UMKM) memiliki peran yang sangat strategis dalam perekonomian Indonesia. Data Kementerian Koperasi dan Usaha Kecil dan Menengah Indonesia tahun 2018 menunjukkan jumlah unit usaha UMKM 99,9\% dari total unit usaha atau 62,9 juta unit. UMKM menyerap $97 \%$ dari total penyerapan tenaga kerja, $89 \%$ di antaranya ada di sektor mikro, dan menyumbang $60 \%$ terhadap produk domestik bruto.

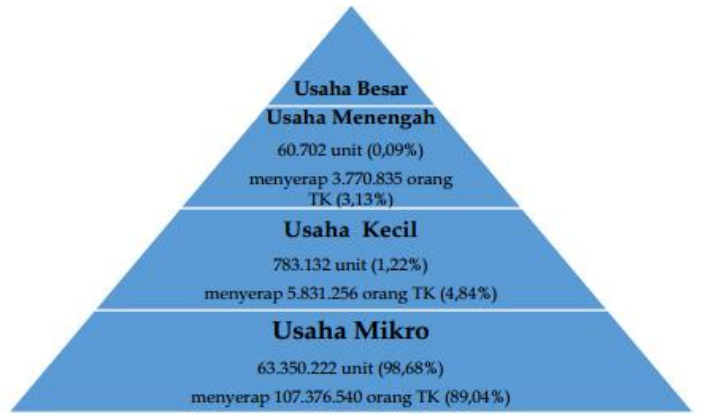

Selama ini UMKM telah membuktikan kemampuannya bertahan dalam situasi ekonomi yang sulit. Sebagian besar UMKM belum berhubungan langsung dengan sektor keuangan domestik, apalagi global. Situasi tersebut menyebabkan UMKM selama ini mampu bertahan terhadap krisis keuangan global seperti pada tahun 1998.

Meskipun telah diketahui ketahanannya dalam menghadapi perlambatan ekonomi, terkait dengan kondisi terkini Ketua Umum Asosiasi UMKM Indonesia (Akumindo) Ikhsan Ingrabatun memperkirakan omset UMKM di sektor nonkuliner turun 30-35\% sejak Covid-19 penyebabnya adalah penjualan produk ini mengandalkan tatap muka atau pertemuan antara penjual dan pembeli secara fisik. UMKM yang menjual produk non-kuliner menyasar wisatawan asing sebagai pasar. Himbauan dari Pemerintah mengenai social distancing yang dicanangkan mulai tanggal 15 .
Maret 2020 juga diprediksi dapat berdampak serius terhadap penyerapan produk UMKM. Maka dari itu, diperlukan perhatian lebih dari pemerintah kepada sector UMKM sebagai penggerak utama perekonomian bangsa.

Maka dari pada itu semakin meningkatkan kasus Corona (Covid-19) di Indonesia akan memperpanjang mimpi buruk bagi pelaku Usaha Mikro Kecil dan Menengah (UMKM) khususnya di Indonesia, belum lagi berbagai kebijakan yang telah dibuat pemerintah seperti Social Distancing (menjaga jarak sosial), Physical distancing (menjaga jarak fisik), dan Pembatasan Sosial Berskala Besar (PSBB) yang akan membatasi mobilisasi masyarakat secara agregat dan akan berdampak pada perlambatan aktivitas ekonomi sehingga akan mempengaruhi secara langsung perilaku masyarakat dalam memenuhi kebutuhanan (supply and demand) akan dibatasi.

Jika melihat dari klasifikasi Usaha Kecil Menengah di Indonesia yaitu : ${ }^{5}$

1. Livelihood Activities, ini mengacu pada sektor non formal seperti para pedagang kaki lima. Di Indonesia sendiri sangat banyak jenis UKM yang seperti ini, yang tentunya akan mundur dengan sedirinya akibat Covid-19.

2. Micro enterprise merupakan UKM pengrajin yang belum memiliki sifat kewirausahaan, UKM ini juga banyak biasa kita temukan di tempat-tempat pariwisata. Yang mana kita semua tahu bahwa pariwisata saat ini seolah-olah mejadi kota mati akibat Pandemi Covid-19 ini, yang akan berdampak langsung pada UKM ini.

3. Small Dynamic Enterprise merupakan pelaku usaha yang sudah memiliki jiwa entrepreneurship dan sudah mampu

5 M. Ainuri, Nilai Ekonomi Modal Sosial Sebagai Media Rekaysa Difusi Teknologi Pada Sentra Industri Pangan Skala Kecil, Kencana, Jakarta, 2009, Hlm 21 
menarik tenaga kerja dan mampu mengekspor hasil produksinya. Jenis UKM ini juga mulai menggigit jari degan banyaknya merumahkan karyawan karena tidak lagi mampu berproduksi. Belum lagi adanya batasan keluarnya masuknya barang anatar Negara sehinga menyebabkan kegiatan ekspor akan terhambat.

4. Fast Moving Enterprise merupakan UKM yang sudah cukup professional dan bertranformasi menjadi sebuah Usaha Besar. Jenis UKM ini juga meskipun sudah cukup profsional pasti akan terinveksi juga akibat Covid-19. Artinya bahwa, hampir semua jenis usaha terinfeksi akibat adanya Pandemi Covid-19.

Sesuai dengan hasil lansir laman news.detik.com bahwa Usaha Mikro, Kecil, dan Menengah (UMKM) menjadi salah satu subsektor yang harus mendapat perhatian karena peran sentral dalam menopang perekonomian di Indonesia. Sekitar $90 \%$ tenaga kerja terserap pada sektor ini dan kontribusinya terhadap PDB sebesar $60 \%$. Jika dirupiahkan kontribusi UMKM terhadap perekonomian nasional Indonesia di tahun 2018 dapat dikatakan cukup besar dengan nilai sebesar Rp 8.400 Triliun.

Maka dari itu jika pemerintah tidak menyelamatkan UMKM maka akan berdampak pada meningkatnya jumlah pengangguran, mengingat UMKM lah yang meyerap hampir 90 terhadap tenaga kerja di Indoensia, karena masyarakat Indonesia lebih banyak yang bekerja pada sektor non formal. Karena UMKM ini merupakan salah satu tombak perekonomian nasional, kita semua berharap bahwa UKM jangan sampai hanya tinggal namanya saja.

Hal demikian tidak membuat pemerintah berdiam diri, tentunya pemerintah memiliki langkah-langkah jitu untuk menyelamatkan UMKM jangan sampai dihantam dan mundur dengan perlahan akibat Covid-19 ini. Langkah tersebut adalah :
1. Melakukan percepatan bagi upaya relaksasi restrukturisasi kredit UMKM yang mengalami kesulitan.

2. Dunia perbankan harus menyiapkan skema baru pembiayaan, terutama berkaitan dengan investasi dan modal kerja yang pengajuannya lebih mudah dengan jangkauan terutama bagi daerah-daerah yang terdampak zona merah.

3. Memasukkan para pelaku usaha mikro atau masyarakat yang membutuhkan dalam skema bantuan sosial, terutama yang berkaitan dengan paket sembako.

4. UMKM diberikan peluang terus untuk berproduksi di sektor pertanian, industri rumah tangga, warung tradisional sektor makanan, dengan menerapkan protokol kesehatan yang ketat.

5. Pemerintah harus tetap konsisten dengan segala kebijakan yang telah dibuat artinya harus ada sanksi yang jelas untuk masyarakat yang melanggar, dan berharap masyarakat harus terbiasa mentaati peraturan yang telah dibuat pemerintah.

Selanjutnya, untuk meyelamatkan UMKM di Indonesia Bapak Teten Masduki selaku Menteri Koperasi dan UKM menawarakan beberapa solusi untuk melindungi UMKM selama Pandemi Covid-19 antara lain : ${ }^{6}$

1. Palama pandemic masyarakat Indonesia harus lebih cinta terhadap produk dalam negeri dalam memenuhi kebutuhannya (cinati produk dalam negeri), dengan demikian akan membuat pelaku UMKM tetap eksis dalam memproduksi barang.

2. Selalu mengefektifkan social distancing dan dalam waktu yang bersamaan pelaku usaha tetap beroperasi dengan menjalankan protocol kesehatan degan baik.

6 Ahmad Muharrom, Adu Strategi dan Lentur Menghadapi Kondisi Perekonomian, Rajawali Press, Jakarta, 2020, Hlm 13 
3. Perbankan harus memberikan subsidi suku bunga pinjaman yang rendah terhadap pelaku UMKM agar mereka tidak kesulitan dalam mendapatkan dana selama pandemic.

4. Melakukan restrukturisasi pinjaman yang khusus bagi koperasi dan UMKM, bila perlu dari segi persyaratan akan lebih dipermudah namun tetap memperhatikan jangan sampai gagal bayar.

5. Masyarakat dan khususnya pelaku UMKM harus selalu menggunakan masker saat berjualan, dan bila perlu pelaku UMKM setiap daerah untuk memproduksi masker tersebut, meskipun usaha pokoknya berhenti namun mereka tetap produktif dengan mencari peluang bisnis baru selama pandemic.

6. Memberikan kartu pra kerja pada pelaku usaha yang rentan dihantam covid-19.

7. Memberikan bantuan langsung tunai (BLT) terutama pada pelaku usahan yang sudah terkena akibat covid-19.

8. Pemerintah harus bersedia mengalokasikan hasil Pph 21, pajak penghasilan inpor dan Pph 25, dan restitusi pajak untuk UMKM.

Meskipun solusi diatas dapat meminimalisir dan membuat UMKM survive, namun selama pandemic ini belum berakhir, maka selama itu pula kekhwatiran bagi para pelaku UMKM akan terus berlanjut. Karena dengan adanya pandemic ini pelaku usaha terkendala dalam hal mendistribusikan barang hasil produksi, terhambat dalam mendapatkan modal usaha, dan dapat menurunkan volume produksi sehingga berdampak pada sedikitnya jumlah barang yang tersedia dan dapat meyebabkan inflasi dan meningkatnya tingakt pengangguran.

Belum lagi berbicara tentang keluar masuknya produk hasil produksi UMKM akan terhambat karena terdapat blockade dan minimnya operasional taransportasi baik udara, laut dan darat, itu akan memperhambat dan mengurangi jumlah barang UMKM bisa diekspor keluar negeri.

Akhirnya, Pandemi Covid-19 masih terus berlanjut, kita berharap ini semua akan ada ujungnya, mari kita sama-sama mentaati semua kebijakan pemerintah dengan mentaati semua protocol kesehatan dengan baik. Kita harus yakin bahwa kita mampu mengembalikan keadaan ini seperti semula. Ini hanya butuh waktu dan butuh persatuan kita dalam melawan Covid-19 ini. Semoga mata rantai Covid-19 ini cepat terputus.

\section{Upaya Pemerintah Memperkuat UMKM}

Guna mengatasi lesunya sector pariwisata, yang memiliki efek besar dalam UMKM, pemerintah berencana menggelontorkan dana sebesar Rp298,5 miliar untuk mendongkrak sektor wisata. Sekitar Rp 73 miliar bakal digunakan Kementerian Pariwisata untuk menggandeng sejumlah influencer atau pemengaruh asing di media sosial yang bisa mempromosikan Indonesia. Sisanya akan digunakan sebagai insentif maskapai dan agen travel, promosi, serta kegiatan pariwisata.

Langkah ini menuai banyak kritik dari masyarakat karena dihawatirkan bakal membuka pintu penularan Covid-19. Pemerintah melalui Surat Keputusan Bersama (SKB) tiga menteri No. 174 Tahun 2020 dan No. 1 Tahun 2020 tentang Perubahan Hari Libur Nasional dan Cuti Bersama 2020 menambahkan hari libur dan cuti bersama yang semula 20 hari menjadi 24 hari. Penambahan empat hari itu adalah 28 dan 29 Mei sebagai cuti bersama Hari Raya Idul Fitri, 21 Agustus sebagai cuti bersama dalam Tahun Baru Islam, dan 30 Oktober sebagai cuti bersama peringatan Maulid Nabi Muhammad SAW. Melalui penambahan hari libur nasional diharapkan dapat menjadi stimulus agar usaha pariwisata bisa meningkat.

Pemerintah pada tanggal 14 Maret 2020 mengumumkan paket stimulus untuk menjaga 
kinerja perekonomian yang tengah tertekan akibat wabah virus Covid-19. Menteri Koordinator Bidang Perkonomian Airlangga Hartarto mengatakan, pada paket stimulus tahap II untuk mengurangi dampak virus Covid-19 ke perekonomian, pemerintah mengalokasikan anggaran Rp22,9 triliun. Jika ditambahkan dengan alokasi anggaran paket stimulus tahap I untuk industri pariwisata, perumahan dan bansos sebesar Rp10,3 triliun maka keseluruhan anggaran pemerintah untuk meredam dampak Covid-19 sebesar Rp33,2 triliun.

Dampak wabah virus Covid-19 merembet hampir ke seluruh sektor industri. Otoritas Jasa Keuangan (OJK) pun menyatakan, untuk meredam dampak industri Covid-19 lebih luas, perbankan bakal memberikan kemudahan pembayaran utang bagi pengusaha sektor usaha mikro kecil dan menengah (UMKM). Ketua Dewan Komisioner OJK Wimboh Santoso mengatakan, kemudahan tersebut bisa berupa menunda pembayaran pokok utang dengan mendahulukan pembayaran bunga kredit.

Pemerintah saat ini masih mempelajari bagaimana keadaan UMKM akibat wabah Covid-19. Kementerian Koperasi dan UKM membuka saluran pengaduan (hotline) melalui Call Center sejak Senin (16/3/2020), pada jam operasional Senin-Jumat, pukul 08.00-15.00 WIB. Call Center ini ditujukan untuk mengetahui kondisi usaha para Pelaku Koperasi \& UMKM yang terdampak wabah Covid-19.

Dari upaya-upaya yang telah dilakukan pemerintah, terlihat masih banyak terpusat pada sektor pariwisata yang memiliki pengaruh besar pada sector UMKM, selain itu kelonggaran kredit juga dianggap sudah tepat untuk meringankan beban UMKM. Namun, bantuan/insentif kepada UMKM khususnya usaha mikro dan kecil masih perlu diperhatikan apalagi mengingat himbauan social distancing saat ini yang berpengaruh besar pada usaha kecil dan mikro yang masih banyak membutuhkan tatap muka.

Terkait dengan urusan pemerintahan, setiap Menteri membidangi urusan tertentu dalam pemerintahan (Pasal 4 ayat 1). Kementerian Koperasi dan UKM RI merupakan Kementerian di kelompok ketiga yaitu urusan pemerintahan dalam rangka penajaman, koordinasi, dan sinkronisasi program pemerintah (Pasal 4 ayat 2, huruf C), berkaitan dengan urusan pemerintahan bidang Koperasi, Usaha Kecil dan Menengah (Pasal 5 ayat 3). UndangUndang telah memberi amanat terhadap pemerintah untuk mengembangkan UMKM. Dalam Undang-Undang No 20 Tahun 2008 tentang UMKM disebutkan peran pemerintah antara lain : ${ }^{7}$

1. Bersama Pemerintah Daerah melaksanakan pengawasan dan pengendalian kesempatan berusaha (Pasal 13).

2. Bersama Pemerintah Daerah melaksanakan kegiatan promosi dagang (Pasal 14, ayat 2).

3. Bersama Pemerintah Daerah memfasilitasi pengembangan usaha dalam bidang produksi dan pengolahan, pemasaran, sumber daya manusia, dan desain dan teknologi (Pasal 16 ayat 1).

4. Menyusun Peraturan Pemerintah mengenai tata cara pengembangan, prioritas, intensitas, dan jangka waktu pengembangan usaha dimaksud (Pasal 16 ayat 3).

5. Bersama dengan Pemerintah Daerah menyediakan pembiayaan bagi Usaha Mikro dan Kecil (Pasal 21). Dalam hal ini Pemerintah, Pemerintah Daerah, dan dunia usaha dapat memberikan hibah, mengusahakan bantuan luar negeri, dan mengusahakan sumber pembiayaan lain yang sah serta tidak mengikat untuk Usaha Mikro dan Kecil (Pasal 21 ayat 4).

7 Sintya, Usaha Kecil Menengah sebagai Potret UKM Indonesia, Gramedia, Jakarta, 2009, Hlm 11 
6. Memberikan insentif dalam bentuk kemudahan persyaratan perizinan, keringanan tarif sarana prasarana, dan bentuk insentif lainnya yang sesual dengan ketentuan peraturan perundang-undangan kepada dunia usaha yang menyediakan pembiayaan bagi Usaha Mikro dan Kecil (Pasal 21 ayat 5).

7. Meningkatkan sumber pembiayaan Usaha Mikro dan Usaha Kecil (Pasal 22).

8. Bersama Pemerintah Daerah, meningkatkan akses Usaha Mikro dan Kecil terhadap sumber pembiayaan (Pasal 23 ayat 1).

9. Bersama dengan Pemerintah Daerah melakukan pemberdayaan Usaha Menengah dalam bidang pembiayaan dan penjaminan (Pasal 24).

10. Bersama Pemerintah Daerah, dunia usaha dan masyarakat memfasilitasi, mendukung, dan menstimulasi kegiatan kemitraan, yang saling membutuhkan, mempercayai, memperkuat, dan menguntungkan (Pasal 25 ayat 1). Kemitraan antar Usaha Mikro, Kecil, dan Menengah dan Kemitraan antara Usaha Mikro, Kecil, dan Menengah dengan Usaha Besar mencakup proses alih keterampilan di bidang produksi dan pengolahan, pemasaran, permodalan, sumber daya manusia, dan teknologi (Pasal 25 ayat 2 ).

11. Menteri Koperasi dan UKM dan Menteri teknis lain mengatur pemberian insentif kepada Usaha Besar yang melakukan kemitraan dengan Usaha Mikro, Kecil, dan Menengah melalui inovasi dan pengembangan produk berorientasi ekspor, penyerapan tenaga kerja, pengunaan teknologi tepat guna dan ramah lingkungan, serta menyelenggarakan pendidikan dan pelatihan (Pasal 25 ayat 3).

12. Menteri Koperasi dan UKM dapat membentuk lembaga koordinasi kemitraan usaha nasional dan daerah untuk memantau pelaksanaan kemitraan (Pasal 34).
13. Melarang Usaha Besar memiliki dan/atau menguasai Usaha Mikro, Kecil, dan/atau Menengah sebagai mitra usahanya dalam pelaksanaan hubungan kemitraan (Pasal 35).

14. Melarang Usaha Menengah memiliki dan/atau menguasai Usaha Mikro dan/atau Usaha Kecil mitra usahanya (Pasal 35).

15. Menteri Koperasi dan UKM melaksanakan koordinasi dan pengendalian pemberdayaan Usaha Mikro, Kecil, dan Menengah (Pasal 38 ayat 1$)$.

16. Mengatur dan menetapkan Peraturan Pemerintah tentang tata cara pemberian sanksi administratif pelaggaran UU Nomor 20 Tahun 2008 Tentang Usaha Mikro, Kecil dan Menengah (Pasal 39 ayat 3).

17. Sehubungan dengan amanat UndangUndang, pemerintah melaksanakan berbagai program yang bertujuan untuk memberdayakan UMKM. Program tersebut antara lain adalah program Gerakan Kewirausahaan Nasional (GKN) dan pemberian Kredit Usaha Rakyat (KUR).

\section{KESIMPULAN}

Berdasarkan uraian diatas, maka penarikan kesimpulannya adalah sebagai berikut

1. Pemerintah telah mengeluarkan beberapa kebijakan terkait perlambatan ekonomi akibat wabah Covid-19 yaitu dengan memberikan insentif di sektor pariwisata, menambah hari cuti bersama, dan keringanan pembayaran utang bagi pelaku UMKM. Selain itu, Pemerintah membuka call center untuk menerima laporan dan pengaduan dari koperasi dan UMKM yang terdampak wabah Covid-19. DPR dengan fungsi pengawasannya perlu mendorong pemerintah untuk memanfaatkan keunggulan geografis ini menjadi peluang apabila pemerintah membangun titik-titik 
UMKM di daerah bebas Covid-19, terutama apabila bertujuan ekspor. Selain itu, pemerintah juga perlu memberikan stimulus untuk menjaga daya beli masyarakat di tengah krisis ini sehingga kemudahan yang diberikan kepada ekonomi dapat terasa manfaatnya. Stimulus tersebut dapat berupa pengurangan tarif listrik dan penurunan harga BBM. Ketersediaan bahan produksi seperti bahan baku juga perlu dijamin supaya kegiatan usaha UMKM tidak terganggu secara signifikan dan mampu kembali ke tingkat produksi normalnya secepat mungkin.

2. Upaya-upaya yang telah dilakukan pemerintah, terlihat masih banyak terpusat pada sektor pariwisata yang memiliki pengaruh besar pada sector UMKM, selain itu kelonggaran kredit juga dianggap sudah tepat

untuk meringankan beban UMKM. Namun, bantuan/insentif kepada UMKM khususnya usaha mikro dan kecil masih perlu diperhatikan

apalagi mengingat himbauan social distancing saat ini yang berpengaruh besar pada usaha kecil dan mikro yang masih banyak membutuhkan tatap muka.

\section{SARAN}

Berdasarkan kesimpulan diatas, maka saran yang dapat penulis berikan adalah sebagai berikut :

1. Untuk Pemerintah, disarankan untuk mengumpulkan pajak dari perusahaanperusahaan besar dan memberikan bantuan modal usaha atau dana tunai pada masyarakat dan usaha mikro kecil dan menengah (UMKM) di tengah ancaman pandemi Covid-19 yang kian berat.
2. Untuk UMKM, perlu menguasai kunci atau tips untuk menghadapinya yaitu fokus pada kebutuhan konsumen, terus berinovasi dan berkreasi, baik di level produk maupun pelayanan sesuai perubahan preferensi dan perilaku konsumen, kembangkan penelitian dan pengembangan untuk meningkatkan daya tahan ketika krisis melanda, tidak boleh cepat berpuas diri karena persaingan akan semakin keras, persiapkan generasi berikutnya untuk menjadi pemimpin UMKM masa depan yang lebih tangguh, jaga hubungan baik timbal balik dengan vendor, supplier dan distributor, berhimpun dalam organisasi UMKM sebagai sarana mengembangkan jejaring dan bisnis, kolaborasi dengan perbankan sebagai mitra strategis untuk sumber pembiayaan, informasi, dan pendampingan pengembangan usaha.

\section{DAFTAR PUSTAKA}

Ahmad Muharrom, Adu Strategi dan Lentur Menghadapi Kondisi Perekonomian, Rajawali Press, Jakarta, 2020

Fahmi Radhi, Kebijakan Ekonomi Pro Rakyat, Republika, Jakarta, 2008

M. Ainuri, Nilai Ekonomi Modal Sosial Sebagai Media Rekaysa Difusi Teknologi Pada Sentra Industri Pangan Skala Kecil, Kencana, Jakarta, 2009

M. Kuncoro, Perencanaan Daerah : Bagaimana Membangun Ekonomi Lokal, Kota dan Kawasan, Gramedia, Jakarta, 2011

Sintya, Usaha Kecil Menengah sebagai Potret UKM Indonesia, Gramedia, Jakarta, 2009

Undang-Undang Nomor 20 Tahun 2008 tentang Usaha Mikro, Kecil dan Menengah (UMKM) 